\title{
NOTES ON THE GLACIER FLUCTUATIONS IN BUNSOW LAND, CENTRAL VESTSPITSBERGEN
}

\author{
By \\ Marjorie SWEETING \\ (School of Geography, Oxford University) \\ and \\ GiLlian Groom \\ (Department of Geography, University College of Swansea)
}

\begin{abstract}
These notes are based on observations made in 1953 on the nature and state of the glaciers in Bünsow Land while the writers were members of the Cambridge Spitsbergen (Physiological) Expedition. Changes in the glacierization of the area, since the compilation of W. B. Harland's map in I 949 , are indicated. These changes illustrate some of the ways in which the thinning and decay of the Spitsbergen glaciers have been brought about.
\end{abstract}

Zusammenfassung. Als die Verfasser im Jahre 1953 Mitglieder der Cambridge Spitsbergen (Physiological) Expedition waren, wurden über die Beschaffenheit und den Zustand der Gletscher in Bünsow Land Beobachtungen gemacht. Änderungen in der Vergletscherung, die seit W. B. Harlands Karte in I949 aufgetreten sind, werden angegeben. Diese Veränderungen weisen auf einige der Arten hin, in denen die Verdünnung der Eisschicht der Spitzbergener Gletscher und die Verwitterung derselben entstanden sind.

THE writers were members of the 1953 Cambridge Spitsbergen (Physiological) Expedition. The base camp of the expedition was at Brucebyen at the northern end of Billefjord, in north-west Bünsow Land. By far the greater part of the geographical work done on the expedition was concerned with obtaining the levelled profiles of the main ice-free valleys of the area, the results of which it is hoped will be published elsewhere, but the following notes on the glacier fluctuations may be of interest.

Bünsow Land lies in the centre of the island of Vestspitsbergen (Fig. I, p. 633). It is a dissected plateau rising to over $700 \mathrm{~m}$. in the south and to over $1000 \mathrm{~m}$. in the north. It is an area of relatively low precipitation-less than $380 \mathrm{~mm}$. a year. The south and south-west is comparatively ice free, partly due to the low precipitation and partly due to a high rate of summer ablation. The glacier cover increases rapidly towards the north and east where in the Lomonosovfonna it reaches ice cap conditions. Thin ice caps occur on many of the broad plateau-like summits of the area, like Templet; these nourish short valley glaciers. The two largest glaciers of Bünsow Land, the Nordenskiöldbreen in the north and the Von Postbreen in the south-east, are outlet glaciers from the Lomonosovfonna; their steep ice fronts are still largely afloat. - Relatively few true corrie glaciers are found in the region. Most of the smaller ice masses are in the form of "cascade" or "slab" glaciers; these glaciers are a distinctive feature of Bünsow Land and are usually roughly triangular in outline and occur on cliffs or valley walls or in gullies, often on slopes as steep as 42 degrees. These "cascade" glaciers were first described by Drygalski in I 9 I I and named by him "Stufenvereisung"1. They have also been referred to by Tyrrell2.*

All the glaciers which were examined in 1953 showed signs of marked recession. Great heaps of moraine were piled up in front of gently sloping glacier snouts; other glaciers terminated in high cliffs of ice which were almost completely covered with moraine. In many places the ice was stagnating at its terminal ends, as in the lateral ice of the southern part of the Nordenskiöldbreen.

The ice fronts of the Nordenskiöldbreen and of the Von Postbreen have in general been in recession since the beginning of the century and have been studied by several expeditions over a number of years ${ }^{3}, 4,5$. Between 1938 and 1949 the rate of recession of the Nordenskiöld ice front averaged from approximately $2 \mathrm{~m}$. to $5 \mathrm{~m}$. a year. Mr. Harland's work since 1949 , which it is hoped will be available soon, suggests that the recession is still continuing6.

The recent changes in the other glaciers of Bünsow Land are indicated in Fig. I. Harland's map, which is used as a basis for Fig. $\mathrm{I}$, is a compilation made from the results of many expeditions over the period $1925-49^{3}$. Much of the northern part of the map is based on surveys made by the

* There appears to be some distinction between these glaciers and hanging glaciers in rudimentary or vestigial form. $-E d$. 
Cambridge expedition in 1938 and most of the southern part is based on the Norwegian photogrammetric survey of $c$. 1925. Hence the changes shown in the glaciers in Fig. I are in the north largely the changes between 1938 and 1953 , and in the south those between approximately 1925 and 1953 . From Fig. I it will be seen that the snouts of many of the valley glaciers show a distinct recession with evidence of thinning. Further, the corrie glacier of Wotherspoonbotnen is now entirely separated from the small plateau ice cap on Campbellryggen and the ice in Nordbotnen is now becoming detached from Mathewbreen. In north-east Bünsow Land, Rinkbreen and the unnamed glacier to the north of it, have lost "contact" with their plateau ice cap. In addition, many of the "cascade" glaciers shown on Harland's 1949 map have now disappeared : this is particularly so in the western part of the area. Fig. I also shows that a small lake has appeared on the stagnant ice at the junction of the Ferrier moraine with the large lateral moraine on the southern side of Nordenskiöldbreen; another lake, dammed up by the retreating Stenhousebreen, occurs in an unmapped tributary valley.

Ahlmann has indicated that the decay of the Spitsbergen glaciers is probably being brought about by the thinning of the ice caps on the higher ground as a result of increased ablation? This is borne out by the nature of the recession of the glaciers in Bünsow Land, where the existing plateau ice caps are thinning so rapidly that they are becoming unable to replenish their dependent glaciers; in particular, the "cascade" and corrie glaciers, impoverished and detached from their main supply areas, have become dead ice.

A further example of the way in which this recession is taking place was seen in Bjönadalen in south-east Bünsow Land. Here the long confluent snout of a simple confluence system of two glaciers has become stagnant (Fig. 2, p. 633). This stagnant ice mass was in process of being severed from its feed glaciers so that it was becoming a dead ice patch, completely covered with frost-shattered scree. A contributary factor to this development has been the steep-sided and deepsheltered nature of Bjönadalen; under these conditions dead ice may be preserved beneath its scree cover and lie in the valley for a long period. Similar dead ice accumulations were observed elsewhere in Bünsow Land, particularly in the valleys between Usherfjell and Grahamkammen and between Usherfjell and Cowantoppen, where the glaciers have retreated to leave only a much attenuated snout in the valley head. The dead ice in these two valleys was completely covered with scree and in places surface-drainage had become established so that summer-melt streams flowed along the dead ice masses, disappearing at intervals into deep hollows in the ice.

Other evidence of glacial recession in Bünsow Land may perhaps be cited in the occurrence of numerous "talus" cones (often at about ${ }_{5} \circ \mathrm{m}$. above sea level) along the south and south-west coasts; these cones were presumably formed by snowbanks which once existed throughout the year.

We were not able to make any ablation measurements on the ice cap east of Bünsow Land, Lomonosovfonna, but observations were made on this ice cap by some members of the expedition and from their measurements we estimate that during the height of the ablation season in the last weeks of July and the first weeks of August, the rate of ablation of the firn was approximately $29 \mathrm{~mm}$. per day.

We are indebted to the Royal Society and one of us (M.S.) to the School of Geography, Oxford, for financial assistance.

MS. received Io fune, 1955

\section{R E F E R E N C E S}

I. Drygalski, E. von. Spitzbergens Landformen und ihre Vereisung. Abhandlungen der Königlich Bayerischen Akademie

- der Wissenschaften München. Mathematisch-Physikalischen Klasse, Bd. 25, No. 7, r9 I , p. I-61.

2. Tyrrell, G. W. The glaciers of Spitsbergen. Transactions of the Geological Society of Glasgow, Vol. 17, Part 1, 1919-22,

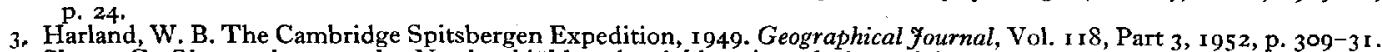

4. Slater, G. Observations on the Nordenskiöld and neighbouring glaciers of Spitsbergen, 1921. Fournal of Geology, Vol. 33, No. 4 , 1925, p. $408-46$.

5. Philipp, H. Ergebnisse der W. Filchnerschen Vorexpedition nach Spitzbergen, I9ro. Petermanns Mitteilungen. Ergänzungsheft No. 179, r914, p. I 3-45.

6. Harland, W. B. Personal communication.

7. Ahlmann, H. W : son. Glaciological research on the North Atlantic coasts. London, Royal Geographical Society, I948, p. 63-7. (R.G.S. Research Series, No. r.) 


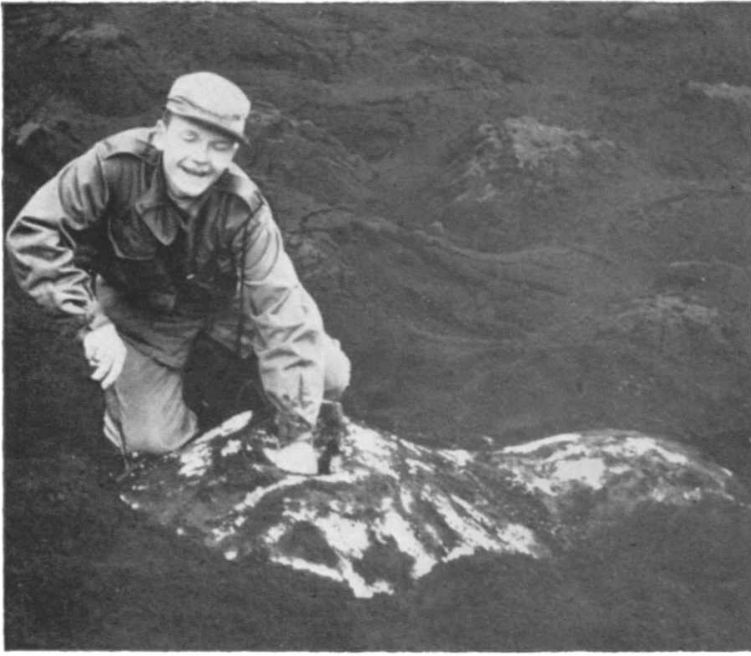

Fig. I (above). Two connected ice cones with ash cover removed. Note technician's hand in crater. Hummocky surface with tension cracks at crests of cones clearly shown (see p. 63T)

Fig. 2 (right). Cone free of ash, showing crater, and surrounding cones beneath ash cover. Lighter colored crests are probably due to downward drainage of water in the ash
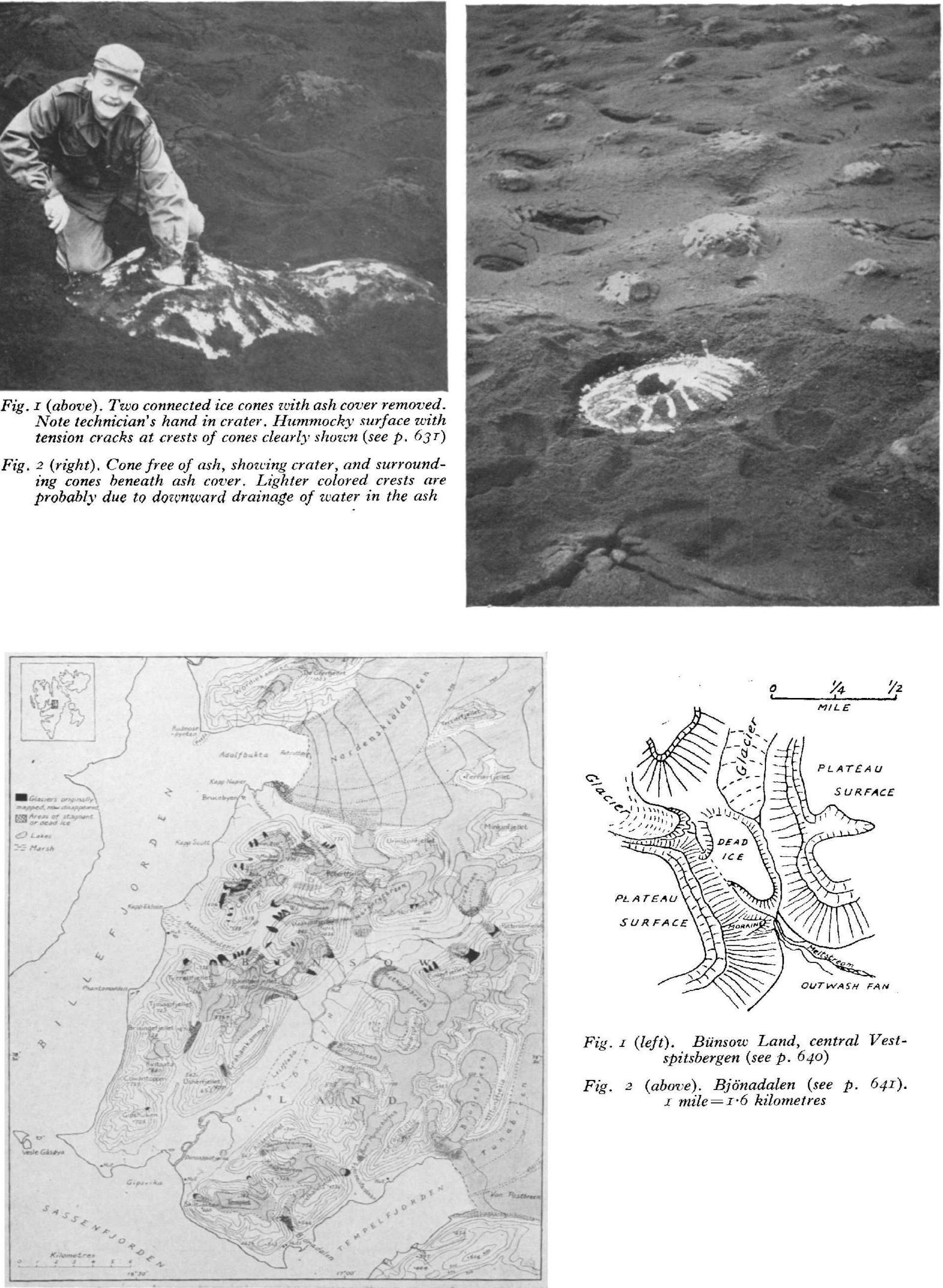

Fig. I (left). Bünsow Land, central Vestspitsbergen (see p. 640)

Fig. 2 (above). Bjönadalen (see p. 64r). $x$ mile $=I .6$ kilometres 